\title{
Relation of HIV-I in bronchoalveolar lavage cells to abnormalities of lung function and to the presence of Pneumocystis pneumonia in HIV-I seropositive patients
}

John R Clarke, Ian K Taylor, Judith Fleming, John D Williamson, David M Mitchell

\begin{abstract}
Background-HIV is present in bronchoalveolar lavage cells of some but not all HIV seropositive patients. Abnormalities of lung function have been described in such patients in the absence of clinically overt pneumonia or other respiratory infections. It is possible that the presence of HIV in alveolar macrophages could account for these abnormalities. It is also possible that the presence of HIV in alveolar macrophages contributes to immunosuppression and an increased incidence of opportunistic infections.
\end{abstract} Methods-This was a prospective study of 157 HIV seropositive patients requiring diagnostic bronchoscopy for investigation of new respiratory symptoms, chest radiograph abnormality, or pneumonic illness. Presence of HIV in bronchoalveolar lavage cells obtained at diagnostic bronchoscopy was determined by polymerase chain reaction to detect proviral DNA and in vitro cocultivation to detect productive virus infection. With these two techniques the presence or absence of HIV in bronchoalveolar lavage was compared with the presence of abnormalities of lung function or presence of Pneumocystis pneumonia.

Results-HIV was detected in bronchoalveolar lavage cells in $65 \%$ of patients by means of the polymerase chain reaction and $59 \%$ with cocultivation. With both methods of detection there was no association between the presence or absence of HIV and the presence of Pneumocystis pneumonia; nor was there a relation between the presence of HIV and abnormalities of lung function.

Conclusion-The presence of HIV in bronchoalveolar lavage cells does not predispose to an increased incidence of Pneumocystis pneumonia; nor does it contribute to abnormalities of lung function.

(Thorax 1993;48:1222-1226)

Alveolar macrophages, which are thought to be important in the defence of the lung against opportunistic infections, are susceptible to infection with HIV. ${ }^{1}$ The most sensitive technique for the detection of HIV in bronchoalveolar lavage (BAL) cells is the polymerase chain reaction. ${ }^{23}$ In one study with this technique, HIV proviral DNA was detected in BAL cells from all of eight patients. ${ }^{2}$ In a more extensive study HIV proviral DNA was detected in the BAL cells from 21 of $44(47 \%)$ patients with respiratory symptoms. ${ }^{3}$ As the polymerase chain reaction detects proviral DNA this technique cannot differentiate between a latent infection where virus is present but is not expressed and a productive infection of the lung where HIV is actively replicating. Virus replication can be shown in clinical specimens by in vitro cocultivation. Several groups have successfully isolated HIV from BAL cells by cocultivation in vitro. The percentage of patients found to have recoverable HIV varied widely, from three of $24(13 \%)$ to 34 of $75(45 \%)$ and 37 of $63(59 \%) .{ }^{4-6}$ Both polymerase chain reaction and cocultivation techniques reveal that HIV is present in the BAL cells of some but not all patients who are HIV seropositive.

Abnormalities of pulmonary function in HIV seropositive patients who do not have clinically overt pneumonia or respiratory infection have been described ${ }^{7}$ and the cause of these abnormalities remains unclear. ${ }^{9}$ Most clinical syndromes associated with HIV are due to the profound immunosuppression resulting from chronic infection with HIV and gradual loss of $\mathrm{CD} 4+$ helper lymphocytes. ${ }^{10}$ It is possible, however, that additional immunosuppression may occur at a local tissue level when cells of other lineages, such as alveolar macrophages, become infected with HIV.

In this study we considered both of these issues. We first looked to see if the presence or absence of HIV proviral DNA in BAL cells 2 detected by the polymerase chain reaction 0 related to the incidence of Pneumocystis pneumonia or abnormalities of pulmonary function. As proviral DNA detected by the polymerase chain reaction may only indicate the presence of a latent or defective virus that is not contributing to pathogenesis, we next looked at the presence or absence of productive HIV infection detected by in vitro coculture of BAL cells and the presence or absence of Pneumocystis pneumonia or abnormalities of lung function. The effects of smoking and $\stackrel{?}{?}$ CD4 peripheral blood cell count are the subject of a separate study. ${ }^{11}$ 


\section{Patients and methods}

One hundred and fifty seven consecutive HIV seropositive patients undergoing investigation for new respiratory symptoms (recent onset of cough, or breathlessness, or both), new abnormal chest radiograph findings, or pneumonic illness were prospectively studied. One hundred and fifty three were homosexual or bisexual men, four were women; intravenous drug users were excluded from the study. Between 48 and 72 hours before bronchoscopy all patients had the following lung function tests performed after a period of rest: forced expiratory volume in one second $\left(F_{E V}\right)$, forced vital capacity (FVC) with a dry bellows spirometer (Vitalograph Ltd, Buckingham, UK), peak expiratory flow (PEF), transfer factor for carbon monoxide (TLCO), and diffusion coefficient (KCO) with the single breath helium dilution method (PK Morgan, Gillingham, Kent, UK). Six patients were either too unwell for pulmonary function testing or the tests were not obtained before the study. Results were expressed as a percentage of predicted normal value. ${ }^{12}$ All values were corrected for haemoglobin. Corrections for ethnicity were made where appropriate. At routine fibreoptic bronchoscopy performed by an experienced bronchoscopist, bronchoalveolar lavage (BAL) with warmed sterile saline was performed in the right middle lobe for diagnostic cytology and for bacteriological and virological culture. A $25 \mathrm{ml}$ aliquot of BAL was obtained for this study and a $20 \mathrm{ml}$ sample of venous blood was taken at the time of bronchoscopy for comparison with BAL cells. Pneumocystis pneumonia was diagnosed on the basis of finding the cyst form of Pneumocystis carinii in the Grocott stained sediment of BAL samples or the trophozoite form with Giemsa stain. Local ethics committee approval for the study was obtained, and informed consent was obtained from each patient before the study.

For HIV-I detection and viral isolation (with full standard laboratory precautions in a category 3 facility) the BAL sample was centrifuged at $1500 \mathrm{~g}$ (MSE Mistral 1000, Leicester, UK) for 15 minutes to deposit cells. The supernatant liquid was discarded and the cells were washed twice in serum free RPMI-1640 cell culture medium (Flow Laboratories, Rickmansworth, UK) containing fungizone $(50 \mu \mathrm{g} / \mathrm{ml})$. Cells in BAL fluid were then counted and viability $(>98 \%)$ was checked with trypan blue. Two million cells

Table 1 HIV proviral DNA detected by the polymerase chain reaction (PCR) and HIV isolated by cocultivation in cells obtained from peripheral blood and bronchoalveolar lavage in HIV-I seropositive patients with respiratory symptoms

\begin{tabular}{|c|c|c|c|c|}
\hline & \multicolumn{2}{|c|}{$\begin{array}{l}\text { Peripheral blood } \\
\text { leucocytes }\end{array}$} & \multicolumn{2}{|c|}{$\begin{array}{l}\text { Bronchoalveolar } \\
\text { lavage }\end{array}$} \\
\hline & $\overline{N A d}$ & $A d$ & NAd & Ad \\
\hline $\begin{array}{l}\text { HIV detected by PCR ( } 157 \text { patients) } \\
\text { HIV detected by cocultivation }{ }^{\star}\end{array}$ & $149(95)$ & $82(52)$ & $83(53)$ & $80(51)$ \\
\hline (100 patients) & \multicolumn{2}{|c|}{$52(52)$} & \multicolumn{2}{|c|}{$59(59)$} \\
\hline
\end{tabular}

NAd-non-adherent cells containing mainly lymphocytes; Ad-adherent cells containing $>98 \%$ monocytes/macrophages.

$\star$ Unseparated cells.

Results are numbers of patients (\%). were then seeded into each well of six well cell culture plates (Sterilin, Hounslow, UK). The cells were stimulated with $1 \mu \mathrm{g} / \mathrm{ml}$ phytohaemagglutinin (PHA-L) and 500 units $/ \mathrm{ml}$ recombinant interleukin-2 (MRC AIDS Directed Programme Repository, Potters Bar, Hertfordshire, UK). To each culture $2 \times 10^{6}$ PHA stimulated cord blood leucocytes were added with a further $5 \mathrm{ml}$ RPMI-1640 medium (Flow Laboratories, Rickmansworth, UK) containing $10 \%$ fetal calf serum, $1.68 \mathrm{~g} / 1$ sodium bicarbonate, $100 \mu \mathrm{g} / \mathrm{ml}$ penicillin, $100 \mu \mathrm{g} / \mathrm{ml}$ streptomycin, and $50 \mu \mathrm{g} / \mathrm{ml}$ nystatin. Peripheral blood leucocytes were prepared from each patient by Ficoll-Hypaque centrifugation and separation, and treated in the same manner as BAL cells.

The polymerase chain reaction analysis for the detection of HIV-I proviral DNA was carried out on samples from all 157 patients, with oligonucleotide primers to the gag and reverse transcriptase regions of the HIV-I genome as previously described.$^{313} \mathrm{~A}$ rigorous technique was employed to avoid cross contamination and in each experiment DNA amplified from a cell line not infected by HIV was run as a negative control. For polymerase chain reaction analysis, the BAL and peripheral blood leucocyte cell populations were divided into adherent (macrophage or monocyte enriched, $98 \%$ of cells were positive for non-specific esterase staining) and nonadherent (macrophage or monocyte depleted) cell fractions by a plastic adherence step of 18 hours in one well of a six well plate. The attempted isolation of HIV by cocultivation for 100 patients in this study was done by culturing patients' leucocytes from BAL or peripheral blood with cord blood leucocytes. The cultures were incubated in an atmosphere of $5 \%$ carbon dioxide for 28 days. On the first day and thereafter twice weekly the cultures were examined microscopically for a cytopathic effect. Two $\mathrm{ml}$ of culture supernatant were carefully removed, $1 \mathrm{ml}$ was stored at $-20^{\circ} \mathrm{C}$ for virological examination for p24 antigen and reverse transcriptase assays, and $1 \mathrm{ml}$ was stored in the gaseous phase of liquid nitrogen for further analysis. The p24 antigen enzyme immunoassay and reverse transcriptase assays were undertaken as previously described..$^{14}$ Statistical comparisons were made using the $\chi^{2}$ test and Student's $t$ test.

\section{Results}

Polymerase chain reaction analysis for the detection of HIV-I proviral DNA was carried out on the peripheral blood and BAL cells from all 157 patients and cocultivation analysis for the detection of productive HIV-I virus infection was carried out in 100 of the 157 patients. Table 1 shows the results. HIV-I was detected by the polymerase chain reaction in 149 of 157 (95\%) of the non-adherent fraction of peripheral blood containing the CD4 + lymphocyte enriched fraction and in 82 of $157(52 \%)$ of the adherent peripheral blood leucocyte population (monocyte en- 
riched). In eight patients HIV could not be detected by the polymerase chain reaction in the peripheral blood non-adherent cell fraction; five of these patients had been on long term AZT treatment (>three months) and in the remaining three there were no detectable CD4 + lymphocytes in the peripheral blood leucocyte non-adherent cell fraction. HIV-I proviral DNA was detected in 83 out of 157 (53\%) of non-adherent BAL cell fractions and in 80 out of $157(51 \%)$ of the purified alveolar macrophage samples. Overall HIV-I proviral DNA was detected in one or other of the BAL cell fractions from 102 out of 157 $(65 \%)$ patients. With in vitro cocultivation, productive HIV-I infection was shown in peripheral blood leucocytes from 52 of 100 patients and BAL from 59 of 100 patients. Table 2 shows the relation between the detection of HIV-I proviral DNA by the polymerase chain reaction and lung function tests. There was no difference in any lung function test between patients in whom HIV could be detected in BAL and those in whom it could not. Table 3 shows the relation between the isolation of HIV-I by cocultivation from BAL

Table 2 Relation between detection of HIV-I proviral DNA by the polymerase chain reaction in either adherent or non-adherent $B A L$ cell fractions and lung function tests

\begin{tabular}{lll}
\hline & $\begin{array}{l}\text { HIV detected } \\
(n=102)\end{array}$ & $\begin{array}{l}\text { HIV not detected } \\
(n=55)\end{array}$ \\
\hline FEV $_{1}$ & $\mathbf{8 6 . 6 ( 2 8 \cdot 7 )}$ NS & $\mathbf{8 0 \cdot 2 ( 2 5 \cdot 2 )}$ \\
FVC & $78.0(24 \cdot 5)$ NS & $93.7(20 \cdot 5)$ \\
TLCO & $48 \cdot 7(17 \cdot 6)$ NS & $53.5(18 \cdot 1)$ \\
KCO & $74.9(16 \cdot 2)$ NS & $75.3(20 \cdot 0)$ \\
\hline
\end{tabular}

Values are mean (SD) \% of predicted value.

Table 3 Relation between the isolation of HIV-I by cocultivation from $B A L$ cells and lung function tests

\begin{tabular}{lll}
\hline & $\begin{array}{l}\text { HIV isolated } \\
(n=59)\end{array}$ & $\begin{array}{l}\text { HIV not isolated } \\
(n=41)\end{array}$ \\
\hline FEV $_{1}$ & $84 \cdot 1(33.9)$ NS & $79 \cdot 4(24 \cdot 7)$ \\
FVC $_{\text {TLCO }}$ & $82 \cdot 4(27 \cdot 1)$ NS & $79.0(23 \cdot 1)$ \\
KCO & $46 \cdot 3(19 \cdot 9)$ NS & $46.3(16 \cdot 8)$ \\
\hline
\end{tabular}

Values are mean (SD) \% of predicted value. cells and lung function tests. There was no significant difference between any lung function test and the presence or absence of HIV by cocultivation. Table 4 shows the relation between Pneumocystis pneumonia and the presence or absence of HIV from both adherent and non-adherent BAL cell fractions aso detected by the polymerase chain reaction and also the distribution of HIV in the group of patients whose respiratory illness was not due to Pneumocystis pneumonia. Of the 1040 patients who did not have Pneumocystis pneumonia, 12 had bacterial pneumonia (positive blood or BAL culture), seven had pulmonarya tuberculosis, six had pulmonary Kaposi's sar-̋ coma alone without a positive microbial cul- $\overrightarrow{0}$ ture, 12 had a positive BAL culture forcytomegalovirus-not thought to be a clini- $\vec{\omega}$ cally significant finding as these patients alf recovered without specific antiviral treatment, $\times$ and one patient had adenovirus in BAL. In aco further four patients there was dual infection $\vec{\sim}$ (two cytomegalovirus and bacterial infection; one cytomegalovirus and tuberculosis; one tuberculosis and bacterial infection). In theo remaining 62 patients no specific microbial diagnosis was made although BAL and sputum often grew normal commensal bacteria. All these patients responded to broad spec $-\frac{\mathbb{}}{3}$ trum antibiotics (not cotrimoxazole) and sod were presumed to have had a bacterial or self limiting viral infection. Of the 53 patientse with Pneumocystis pneumonia, 13 had con $\omega$ comitant bacterial infection and one hado tuberculosis and cytomegalovirus. There was no association between the presence of HIV in either cell fraction and the presence of Pneumocystis pneumonia, or other respiratory diagnoses. Similarly HIV was isolated by cocultivation from 23 of 36 (64\%) patients with Pneumocystis pneumonia and from 36 of $64(56 \%)$ patients with other respiratory diag noses. Again the difference in frequency of HIV isolation between the two groups wasn not statistically significant. Table 5 shows the mean TLCO expressed as a percentage of normal for patients with and withoui Pneumocystis pneumonia and with and with-

Table 4 Numbers of patients in whom HIV was or was not detected by the polymerase chain reaction in non-adherent and adherent cell fractions of $B A L$ from patients with Pneumocystis pneumonia $(P C P)(n=53)$ and patients without $P C P(n=104)$

\begin{tabular}{|c|c|c|c|c|c|}
\hline & & \multicolumn{4}{|c|}{ Bronchoalveolar lavage } \\
\hline & & \multicolumn{2}{|l|}{ NAd } & \multicolumn{2}{|l|}{ Ad } \\
\hline & & HIV detected & HIV not detected & HIV detected & HIV not detected \\
\hline \multicolumn{2}{|c|}{$\begin{array}{l}\text { Patients with PCP }(\mathrm{n}=53) \\
\text { Patients without PCP }(\mathrm{n}=104)\end{array}$} & $\begin{array}{l}31 \\
52\end{array}$ & $\begin{array}{l}22 \\
52\end{array}$ & $\begin{array}{l}27 \\
53\end{array}$ & 26 \\
\hline \multicolumn{6}{|c|}{$\begin{array}{l}\text { NAd-Non-adherent cells; Ad-adherent cells. } \\
\text { There was no statistically significant relation between presence or absence of HIV and PCP or non-PCP pneumonic illness. }\end{array}$} \\
\hline \multicolumn{6}{|c|}{$\begin{array}{l}\text { Table } 5 \text { Mean (SD) TLCo expressed as percentage of normal for patients with and without Pneumocystis pneumonia } \\
(P C P) \text { where HIV was or was not detected by the polymerase chain reaction }\end{array}$} \\
\hline & \multicolumn{5}{|c|}{ Bronchoalveolar lavage } \\
\hline & \multicolumn{3}{|c|}{ NAd } & \multicolumn{2}{|l|}{ Ad } \\
\hline & HIV detected & \multicolumn{2}{|c|}{ HIV not detected } & HIV detected & HIV not detected \\
\hline $\begin{array}{l}\text { PCP } \\
\text { Non-PCP }\end{array}$ & $\begin{array}{l}41.9(16.0) \mathrm{NS} \\
57.0(18.7) \mathrm{NS}\end{array}$ & \multicolumn{2}{|c|}{$\begin{array}{l}41 \cdot 8(13 \cdot 8) \\
61 \cdot 3(10 \cdot 4)\end{array}$} & $\begin{array}{ll}42 \cdot 8(15 \cdot 7) & N S \\
63.4(18 \cdot 2) & N S\end{array}$ & $\begin{array}{l}42.5(15 \cdot 6) \\
65 \cdot 0(16 \cdot 4)\end{array}$ \\
\hline
\end{tabular}

NAd and Ad as defined in table 4. 
out HIV detected in cell fractions of BAL by the polymerase chain reaction. The presence of HIV had no additional effect on TLCO in any patient group.

\section{Discussion}

In the present study we have confirmed and extended the findings that HIV-I can be detected in bronchoalveolar lavage cell populations of some but not all HIV seropositive patients and that the presence of HIV-I can be shown both by the polymerase chain reaction to detect proviral DNA and by cocultivation in vitro to demonstrate productive viral infection. ${ }^{313}$

We next asked two questions: does the presence or absence of HIV-I in bronchoalveolar lavage cells have any influence on abnormalities of pulmonary function or does the presence of the virus predispose to opportunistic lung infections, in particular Pneumocystis pneumonia. We first used the polymerase chain reaction to detect proviral DNA and found that $65 \%$ of our patients had HIV detectable in one or other of their BAL cell fractions. We were thus able to look at our two patient groups where HIV was present and absent to see if presence of the virus had any effect on pulmonary function tests, in particular TLCO, and the presence of Pneumocystis pneumonia. We found that it did not. As the polymerase chain reaction detects proviral DNA, which may represent a latent virus infection or defective viral infection incapable of replication and therefore unable to have a pathogenic effect, we next looked for the ability of HIV to be cocultured in vitro from BAL cells. We found that in $59 \%$ of our patients HIV could be recovered by culture and again we were able to look at two patient groups, where HIV was present and absent, and compare effects both on pulmonary function tests, in particular TLCO, and the presence or absence of Pneumocystis pneumonia. Again we found that the presence of HIV did not influence pulmonary function tests or the presence of Pneumocystis pneumonia. We therefore conclude that the presence of HIV-I in BAL cells does not make an additional contribution to immunosuppression to the extent that this is manifest by an increased incidence of Pneumocystis pneumonia or other respiratory illness. We also conclude that the presence of HIV-I does not make an additional contribution to the abnormalities of lung function described previously. ${ }^{8}$

On the basis of this study it seems that the mere presence of the virus does not affect either of these features. Others have reported, however, that after seroconversion, HIV-I specific CD8 + cytotoxic lymphocytes (CTLs) appear in the lung and that this is related to the non-specific alveolitis recorded in HIV-I seropositive patients. ${ }^{16}$ As well as the presence of HIV in the lung the presence of CTLs may also be required for pathological changes that could account for the abnormal lung function tests described in these patients. ${ }^{8}$ It seems that HIV-I specific CTLs can initiate inflammatory changes in the lung, ${ }^{17}$ and $\mathrm{CD} 8+, \mathrm{D} 44+$ CTLs can be detected in BAL in the absence of opportunistic lung infections or tumours in HIV-I seropositive patients. In one study nonspecific interstitial pneumonitis was seen in $38 \%$ of AIDS patients ${ }^{18}$ and accounted for $32 \%$ of episodes of clinical pneumonitis in HIV-I seropositive patients. Further investigation by these workers showed that after transbronchial biopsy 11 of $23(48 \%)$ patients had histological evidence of chronic interstitial pneumonitis. ${ }^{19}$ Infiltrative CD8 lymphocytosis in BAL fluid has been linked to the presence of HLA-DR5 and seems to be a genetically determined host response to HIV. ${ }^{20}$ A clear causal link between the presence of CTLs specific for HIV and the generation of lung disease and ensuing abnormalities of lung function or pulmonary opportunistic infections remains to be established. If, in due course, it is, this would suggest that the host response to HIV in the lung may be important in pathogenesis as the present study shows that the mere presence of $\mathrm{HIV}$ in BAL fluid neither contributes to abnormalities of lung function nor predisposes to pulmonary opportunistic infections.

We thank Siobhan Crossan for typing the manuscript. This work was supported by the Medical Research Council AIDS Directed Programme.

1 Salahuddin SZ, Rose RM, Groopman JE, Markham PD, Gallo RE. Human T lymphotrophic virus type III infection of human alveolar macrophages. Blood 1986;68: $281-4$

2 Rose RM, Krivine A, Pinkston P, Gillis JM, Huang H, Hammer SM. Frequent identification of HIV-I DNA in bronchoalveolar lavage cells obtained from individuals with the acquired immunodeficiency syndrome. $A m$ Rev wespir Dis 1991;143:850-4.

3 Clarke JR, Krishnan V, Bennett J, Mitchell D, Jeffries DJ. Detection of HIV-I in human lung macrophages using the polymerase chain reaction. AIDS 1990;4:1133-6.

4 Dean NC, Golden JA, Evans LA, Warnock ML, Addison TE, Hopewell PC, et al. Human immunodeficiency virus recovery from bronchoalveolar lavage fluid in vatients with AIDS. Chest 1988;93:1176-9.

5 Jeffrey AA, Israel-Biet D, Andriev JM, Even P, Venet A. HIV isolation from pulmonary cells derived from bronchoalveolar lavage. Clin Exp Immunol 1991;85:488-92.

6 Clarke JR, Williamson JD, Mitchell DM. A comparative study of the isolation of human immunodeficiency virus type 1 from the lung and peripheral blood of AIDS type 1 from the lung and peripheral

7 Shaw RJ, Roussak C, Forster SM, Harris JRW, Pinching AJ, Mitchell DM. Lung function abnormalities in patients infected with the human immunodeficiency virus with and without overt pneumonitis. Thorax 1988; 43:436-40.

8 Mitchell DM, Fleming J, Pinching AJ, Harris JRW, Moss $\mathrm{FM}$, Veale $\mathrm{D}$, et al. Pulmonary function in human immunodeficiency virus infection: a prospective eighteen month study of serial lung function in 474 patients. Am Rev Respir Dis 1992;146:745-51.

9 French PD, Cunningham DA, Fleming J, Donegan C, Shaw RJ, Mitchell DM. Low carbon monoxide transfer factor (TLCO) in HIV infected patients without lung disease. Respiratory Medicine 1992;86:253-6.

10 Murray JF, Mills J. Pulmonary infectious complications of human immunodeficiency virus infection part 1. Am Rev Respir Dis 1990;141:1356-72.

11 Clarke JR, Taylor IK, Fleming J, Nukuna A, Williamson JD, Mitchell DM. The epidemiology of HIV-I infection of the lung in AIDS patients. AIDS 1993;7:555-60.

12 Cotes JE, Lung function: assessment and application in medicine, 4th ed. Oxford: Blackwell Scientific, 1979.

13 Clarke JR, Fleming J, Donegan K, Nieman R, Williamson JD, Mitchell DM. Effect of HIV-I and cytomegalovirus in bronchoalveolar lavage cells on the transfer factor for lung carbon monoxide in AIDS patients. AIDS 1991;5: 1333-8. 
14 Moore JB, McKeating JA, Weiss RA, Satentau QJ. Dissociation of gp 120 from HIV-1 virions induced by soluble CD4. Science 1990;250:1139-42.

15 Potts BJ. "Mini" reverse transcriptase assay. In: Aldovini A, Walker BD, eds. Techniques in HIV research. New York: Stockton Press, 1990: 103-6.

16 Plata F, Dadaglio G, Chenciner N, Hoffenbach A, WainHobson S, Michel F, et al. Cytotoxic T lymphocytes in HIV induced disease: implications for therapy and vaccination. Immunodefic Rev 1989;1:227-46.

17 Autran B, Mayaud CM, Raphael M, Plata F, Denis M, Bourguin $A$, et al. Evidence for cytotoxic $T$ lymphocyte alveolitis in human immunodeficiency virus-infected patients. AIDS 1988;2:179-83.

18 Suffredini AF, Ognibene FP, Lack EE, Simmons JT,
Brenner M, Gill VJ, et al. Non-specific pneumonitis: a common cause of pulmonary disease in the acquired immunodeficiency syndrome. Ann Intern Med 1988;107: 7-13.

19 Ognibene FP, Masur H, Rogers P, Travis WD, Suffredin AF, Feverstein I, et al. Non-specific interstitial pneumonitis without evidence of Pneumocystis carinii in asymptomatic patients infected with human immunodeficiency virus (HIV). Ann Intern Med 1988;10\% 874-9.

20 Itescu S, Brancato LJ, Buxbaum J, Gregersen PK, Riz CC, Croxson TS, et al. A diffuse infiltrative CD8 lym phocytosis syndrome in human immunodeficiency virus (HIV) infection: a host immune response associated with HLA-DR5. Ann Intern Med 1990;112:3-10.

\section{Adventitia}

\section{To Egypt — with my defibrillator}

\section{Prologue}

A wealthy Sheikh decides to invest in a major building project in his native city but, instead of using his own money, wishes to secure a large loan from a major Arab bank. He hires, as his agent and contact man, a shrewd wealthy Arab businessman whom we shall call X.

In May $1977 \mathrm{X}$ was admitted to our Coronary Care Unit with an inferior myocardial infarct (Day 1). Within 30 minutes he had a cardiac arrest due to ventricular fibrillation from which he was promptly and successfully resuscitated by my junior staff. His subsequent medical progress was uneventful, but I was then informed that he was returning to Cairo by Day 11 in order to conclude a $£ 20$ million business deal. My initial reaction was to say "no chance", until told that the patient would be accompanied by his personal medical attendant who would take full responsibility for his management. Suitable arrangements would be made for boarding and reception at the other end and, of course, the flight would be first class. Much to their chagrin, I informed my junior staff that this was a job for men not boys; I assembled a bag containing the wherewithal for intubation, various drugs, and a small portable, battery operated, defibrillator. On Day 9 we were ready to depart.

The scene changes to the exotic surroundings of a plush hotel near Heathrow. A meeting had been arranged with the other UK based partners of which I only learned on the way to London and tried to dissuade him from attending. My worst fears were then realised. Far from being amicable, the meeting became increasingly acrimonious over the amount of commission to be paid to each participant. No agreement could be reached and I became concerned about the effects of catecholamine release on my patient's (and my own) myocardium. The main participants were eventually separated by a lawyer and we retired to eat and rest. The following morning we departed for Cairo-an uneventful budo truly luxurious flight-and arrived to a hero's welcome. My patient was engulfed by various: members of his large family and greeted effurt sively. We then embarked in a fleet of limouo sines for the centre of Cairo-a hair-raising. and high speed experience which anyone familiar with travelling in that city will knows With immense relief I delivered him safe sound and asymptomatic to the Cardia量 Institute and his local cardiologist.

This should have been the end of the story 50 but $\mathrm{X}$ was keen for me to stay on for a time and I accompanied him the next day (Dag 11) to a major bank where he had to negots ate exhaustively, but eventually successfully with the manager over the massive loan. pleasant interlude sightseeing was followed bo an emergency call in the early hours of th $\overrightarrow{\vec{E}}$ morning to a nursing home where he was now in mild left ventricular failure; I adminise tered morphine intramuscularly and fruse mide intravenously and he recovered. He wat then well enough to insist that I visited some of the marvels of ancient Thebes, and I spen an unforgettable two days visiting the Temples of Karnak and the valleys and tombs of the Kings and Queens, flying home ow Day 17.

It was perhaps the strange combination of medical hazard and a glimpse into the turbure lent world of high finance which made this trip seem more like a month than the actual week it spanned. On my return colleagues were singularly unimpressed by my trip to Cairo; they thought I had been visiting Caerau, a small mining village near Bridgen

\section{Epilogue}

Sadly the building project was never com $\frac{0}{0}$ pleted. X continued to smoke heavily and th work 12 hours a day. Some years later he hađ coronary artery bypass grafting performed i London. We keep in touch, indeed he was if London only recently with a sick grandchil\& $\mathrm{He}$ is well.

GUY CHAPPEI 